\title{
Need Analysis of English Material in the Second Third Grade Elementary Program
}

\author{
Naili Adilah Hamhij \\ English Departmen \\ Universitas Islam Negeri Raden Intan \\ Lampung, Indonesia \\ nayhamhij@gmail.com
}

\author{
Hariyanto \\ English Departmen \\ Universitas Islam Negeri Raden Intan \\ Lampung, Indonesia \\ hariyantosr3592@gmail.com
}

\author{
Zakiyah \\ English Departmen \\ Universitas Islam Negeri Raden Intan \\ Lampung, Indonesia \\ zakiyahansori@gmail.com
}

\begin{abstract}
Designing English content materials for Elementary students particularly second-third grade is important because it may be supported the goal of English teaching learning. This research done was based on the students' need, students' pre assessment, observation, students, teachers, and parents questionnaires, which have shown in the following activities: 1) second-third grade students are grouped in one class which means that they have different stage abilities of learning ; two) the students who are still in the lower grade ( second grade) struggles in grasping the materials ; 3) teachers need to provide various materials to facilitate the students in the learning process; 4) the existing-in use materials are designed for the higher grade (third grade) assuming they are eager to teach peers. The data analysis process required a number of steps that fulfilled the needs of all the participants involved, namely: Discussion with the school stakeholders, Semi-structured interviews with the target group teachers, Interviews with the target group students, and Open-ended, structured questionnaires for students. From the research, it was found that students feel difficult in teaching learning and it was too complicated materials. From the research interview, observation and questionnaire it can be analyzed that students are able only in speaking skill.
\end{abstract}

Keywords-Need Analysis, Elementary Program, English Material, English Curriculum, Instructional Curriculum.

\section{INTRODUCTION}

Curriculum in Indonesia has become a long discussion for our education, there are many changes and developments of the curriculum used for all schools in this country, whether it is line with the school's need or not. Curriculum plays as a major part in education field, as it directs the teaching and learning processes in the classroom. Because it's the first element must existed and arranged in education, that is why the curriculum should be planned well. [1] Curriculum for all level and genre are developing appropriate with verified to Education denomination, territory potential, and students. [2] The need analysis of the curriculum is the procedures to collect information about learners' needs. In short, school as the formal education has implemented various curriculums in order to improving the successful in the mastery English.

Mastery of English is the key to success for individuals, communities and the nation of Indonesia field in this era. Activities to develop and improve the English language competency can be done in various ways and various places. But children of Indonesia mostly use and take advantage of acquisition activity lesson in English formal schools. Then formal education becomes the main focus of learning English will be the provision of Indonesian children in treading their future lives [3].

School as the formal education has implemented various curriculums in order to improving the successful in the mastery English. Curriculum in Indonesia has become a long discussion for our education, there are many changes and developments of the curriculum used for all schools in this country [4], whether it is line with the school's need or not. Curriculum plays as a major part in education field, as it directs the teaching and learning processes in the classroom. Because this is the first element must existed and arranged in education, that is why the curriculum should be planned well.

Based on UUD No.02 year 2003 relate to National System of Education section 36 verse (2) districted that "Curriculum for all level and genre are developing appropriate with verified to Education denomination, territory potential, and students" Based on this consideration, the curriculum need to develops better and better, because curriculum is the basic plans for education. It has to be concern not only from the academic, but also concern to the student's psychology and mentally [5]. If all the elements complete, we can educate and prepare children for their future.

English is already became a scary paradigm since it announced become an international language, there are 
lots of school offered the English program in their school [6]. Their teach English from Kindergarten till University, they think English is the most important language for now to be implemented in the work place and in the real life. This paradigm makes almost all parents willing their children are able to mastered English. Why private schools have their own curriculum? Because they are able to develop and create their own curriculum, because they think the curriculum from government is not appropriate and is not suitable with the students' condition [7]. One of the private schools which have their own curriculum is Tunas Mekar Indonesia, this school adopt the curriculum from Cambridge. The curriculum concern with an English language as their daily language, the curriculum which concern to their students' English four basic skill and also students' needs for their future. They tried to answer the parents' worry for the perception that English will always use in every part of life. This paradigm really able to scare all parents, they do not want their children left behind because of they are not mastering the English language [8].

The effort of government in changing the curriculum was not enough without improving the quality of English teacher and also the important one is the renewal of materials that will be suitable with students' need and characteristic of the students [9]. According to Richards (2001), the need analysis of the curriculum is the procedures to collect information about learners' needs. Need analysis is considered a crucial component of systematic curriculum development. It is also to see what happened and what is needed after the teaching learning processes in the classroom [10]. It supported by McKillip (1987), "Needs are value judgments: that a target group has problems that can be solved." The term 'need' is not straight forward as it might appear, and hence the term is sometime use to refer to wants desire, demands, expectation, motivation, lacks, constrains, and requirements (Brindley 1984, 28). Therefore, students' need analysis is the way to find out students need in teaching learning English.

Beside students need, material in teaching learning is also the important one to improving the goals of education to mastery English [11]. Tiwari (2008) explained that material is a tool to achieve the goals of teaching learning; it can be help teacher to prepare the exercises, guide the students in teaching learning process and also material in the class make the students serious and have a mission to be achieve (Richards and Schmidt, 2002: 339). Moreover, Choudhury [12] explained that teaching material has a function as the guide in order to avoiding any missing elements or unnecessary repetition.

This research conducted in Sekolah Tunas Mekar Indonesia grade 2 and 3 because in this school not only English as school subject but also English used for daily so this school also prioritizes the life skill education in every activity they do. They try to make a good blend between academic and the life skill education delivered by English language for their daily activities in the class, outside the class, announcement, wall magazines, and etc.

This school has been able to implement the right mix of international and national based courses and so improve the quality of the learning. Nevertheless, there are a lot of Indonesian schools struggling with this development, because the people responsible for implementing and developing this school-based curriculum, lack the professionalism to take on this complicated task, the level of material is too high, and sometimes not suitable with the students need.

This paper is structured as follows: the first section is about Sekolah Tunas Mekar Indonesia English Curriculum, whether it is appropriate with students ability or not. Secondly, the materials in teaching learning process in the class. The last section about evaluation can be made as the basic information for all policy decisions relate to educational elements of second grade level of Elementary School in Tunas Mekar Indonesia. Finally, the paper concludes by summarizing all the findings.

\section{RESEARCH QUESTION}

\section{A. Research Question}

Based on the background of the problem above, the writers take the questions of the research as follows:

- What do the students' needs in English teaching learning process?

- What are the appropriate English content materials regarding to students need?

\section{B. The Objective}

Particularly the objectives of this study are:

- To find out students need in English teaching learning.

- To determine the appropriate English content materials regarding to the students need.

\section{RESEARCH METHOD}

The research is aimed to find out students need in English teaching learning in 2-3 grade students of Sekolah Tunas Mekar Indonesia which has been established as one of Indonesia's National Plus, located in Jalan Arif Rahman Hakimm no 36 Jagabaya, Bandar Lampung TB. Determining the appropriate English content materials for Elementary students particularly 2-3 grade, was based on the students' need, students' pre assessment, observation, students, teachers, and parents questionnaires, which have shown in the following activities: 1) 2-3 grade students are grouped in one class which means that they have different stage abilities of learning ; 2) the students who are still in the lower grade ( 2 nd grade) struggles in grasping the 
materials ; 3) teachers need to provide various materials to facilitate the students in the learning process; 4) the existing-in use materials are designed for the higher grade (3rd grade) assuming they are eager to teach peers.

The research design took a multiple sources or methods approach and to triangulate the findings lead to increase the credibility of the data. Multiple sources covered documents, interviews, and field observations. According to Long, as cited by Jeremy Cowling in the journal (2007) [14], guarantees that a huge form of statistics may be amassed and in comparison, and that the methods of doing this (along with via gathering informants' intuitions, interviews, surveys, language audits, observations, journals, assessments and so on) taking into consideration distinct kinds of records to be accumulated. . As lengthy states, "it's far tough to overemphasize the chance that use of a couple of measures, as well as multiple sources, will increase the nice of records gathered" (2005, p. 32) and this has been concurred with with the aid of some essential NA studies (2005, p. 32) and this has been concurred with by some important NA studies (e.g. Chaudron et al., 2005; Cumaranatunge, 1988; Gilabert, 2005; JassoAguilar, 2005; Sullivan \& Girginer, 2002) [15].

The participants of the research was chosen randomly include 24 students who are from two classes out of seven classes of 2-3 grade students, 1 teacher who teaches from grade 2-3 A, and 24 parents who chosen randomly. This research also involved document as multiple sources, which are pre assessment results, observation sheets, curriculum mapping, lesson plan, and the students' workshop results. In addition, the student participants answer the Need Analysis form which is adapted from Nation and Macalister (2009) [17]. Class observations (Yalden,1987) [18] became any other region of need analysis that might had been pursued, however scheduling and time constraints factored in opposition to this method and it is arguable whether or not this would monitor any beneficial details about the real desires of the students. It transpired that the use of 'informants' would have to play a chief function within the want analysis studies system. Through interviews and questionnaires relevant data could be accumulated from differing assets and in comparison. the usage of questionnaires (Al-Khatib, 2005; Bosher \& Smalkoski, 2002; Jordan \& Mackay, 1973; Li So-mui \& Mead, 2000; Mackey \& Bosquet, 1981; Richterich \& Chancerel, 1977) [19] could permit for informant input, a manner this is "the most common approach of desires analysis" (West, 1994), as could firstly unstructured interviews (e.g. Chaudron et al., 2005; Lincoln \& Guba, 1985; long, 2005) after which dependent interviews (Fixman, 1990; Gilabert, 2005) [20].

The data analysis process required a number of steps (as discussed by Schutz \& Derwing, 1983) [21] in which the effective use of informants was to be the key to producing a syllabus that fulfilled the needs of all the participants involved.

Step 1: dialogue with the school stakeholders. via conducting an open-ended questions interview, it was was hoping that the interviewees would openly provide more distinctive money owed as opposed to being "restrained by way of a fixed of pre-deliberate questions" (long, 2005, p. 36) [22].

Step 2: Semi-established interviews with the target group teachers. these informers are basically 'outsiders' or "non-professionals" (lengthy, 2005, p. 35) [23] as even though they will be experienced language instructors inside the target college students. but, interviewing these instructors might with a bit of luck provide beneficial insights (Chaudron et al., 2005) [24] into their college students' language ability and some of the college's operations or administrations.

Step 3: Interviews with the goal group students. using target students as informers seems an apparent desire, and are regularly the "primary, every now and then the only, respondents" (lengthy, 2005, p. 19) (see, e.g., Alalou, 2001; Lepetit \& Cichocki, 2002) [25]. The fulfillment of the effects from this supply depends on how well informed the students are and whether they're "pre-revel in", "pre-provider" or "in-provider" newbies (long, 2005, p. 20) [26].

Step 4: Open-ended, structured questionnaires for students to complete with their senior students. At this point the research was looking for a new perspective from a source that had experience in the target situation as well as in previous English language syllabus at Tunas Mekar Indonesia School. These informants, known as 'domain experts', can provide quality information about the tasks they undertake, especially in the case of when English is required.

\section{A. Data Analysis}

Data from the research were analyzed and displayed by a presentation in the form of table and bar chart consists of student questionnaire, parent questionnaire, and teacher interview.

\section{FINDINGS AND DISCUSSION}

\section{A. Findings}

The findings cover the students need and all instruments about materials, students' questionnaire, teacher's interview and parent questionnaire based on students' needs in teaching learning English for the 2-3 grade students of TMI (Tunas Mekar Indonesia).

\section{B. Materials}

In the teaching learning, criteria in selecting the materials are very important, and it should be developed in instructional design such as: the criteria of instructional goals, the clear materials, and relevant based on student need. In this research there are some points in English subject. 


\section{Students' Questionnaire}

In the questionnaire, students answered how their respond in English. The folowing questions are the students' questionnaire that indicates the students need in the teaching and learning process.

TABLE I. STUDENTS' QUESTIONNAIRE SHEET

\begin{tabular}{|l|l|c|c|}
\hline No & \multicolumn{1}{|c|}{ Question } & \multicolumn{2}{c|}{ Answer } \\
\hline 1 & Do you like the English subject? & Yes & No \\
\hline 2 & Is the text book interesting? & Yes & No \\
\hline 3 & Is the English material suitable for you? & Yes & No \\
\hline 4 & Are the objective is clear? & Yes & No \\
\hline 5 & Is teacher explanation is clear? & Yes & No \\
\hline 6 & \multicolumn{3}{|c|}{ Are the materials: } \\
\cline { 2 - 5 } & Attractive? Is the time allocation: & Yes & No \\
\cline { 2 - 5 } & Easy to duplicate? & Yes & No \\
\hline 7 & \multicolumn{3}{|c|}{} \\
\cline { 2 - 5 } & Just right? & Yes & No \\
\cline { 2 - 5 } & Too short? & Yes & No \\
\cline { 2 - 5 } & Too long? & Yes & No \\
\hline 8 & \multicolumn{3}{|c|}{} \\
\cline { 2 - 5 } & Easy to follow/teach? & Yes & No \\
\cline { 2 - 5 } & Interesting? & Yes & Yes \\
\cline { 2 - 5 } & Relevant to the learning process? \\
\hline
\end{tabular}

TABLE II. SHOWS THE RESULT IN THIS REGARD

\begin{tabular}{|c|c|c|}
\hline Statement (Points) & Yes & No \\
\hline 1 & $100 \%$ & - \\
\hline 2 & $20 \%$ & $80 \%$ \\
\hline 3 & $22 \%$ & $78 \%$ \\
\hline 4 & $82 \%$ & $18 \%$ \\
\hline 5 & $83 \%$ & $17 \%$ \\
\hline 6 & $88 \%$ & $12 \%$ \\
\hline 7 & & \\
a. & $19 \%$ & $81 \%$ \\
b. & $14 \%$ & $86 \%$ \\
c. & 97 & $3 \%$ \\
\hline 8 & & \\
a. & $12 \%$ & $88 \%$ \\
b. & $86 \%$ & $14 \%$ \\
c. & $20 \%$ & $80 \%$ \\
\hline
\end{tabular}

\section{Finding}

- All of respondent like English it showed by $100 \%$.

- Almost all respondent interested in the text book used $80 \%$ of students.

- Only $22 \%$ respondent feel that the materials suitable for them.

- The objective are clear showed by $83 \%$ of respondent understand the objective of teaching learning.

- The objective almost all the respondent say yes $82 \%$

- Teacher explanation is clear about almost all respondent $88 \%$.
- The time allocation is too long it showed by $97 \%$ respondent, too short only $19 \%$ and $14 \%$ said that just right time allocation.

- The activity during teaching learning $86 \%$ said that it is very interesting, but almost all respondent $88 \%$ fell it is difficult to follow and also only $20 \%$ respondent said that the activity is relevant in teaching learning process.

Based on the findings of table 1.1, it could be concluded that all students like English and the teacher's teaching way. Unfortunately, most of them still found difficulties to understand the material because of the textbook material which is not suitable for them. The students felt that the learning process activities were difficult to understand and not relevant to the learning process.

\section{E. Teacher Interview}

In the interview, the teacher answered how his respond in English. The folowing questions are the 
teacher's interview guideline that indicates the teacher's respond in the teaching and learning process.

TABLE III. TEACHER INTERVIEW

\begin{tabular}{|c|c|c|c|}
\hline No & Point of interview & Questions & Notes \\
\hline 1 & Teaching and Learning Objectives & $\begin{array}{l}\text { Are the English teaching objectives appropriate } \\
\text { with Sekolah Tunas Mekar Indonesia English } \\
\text { subject curriculum? Would you give explanations? }\end{array}$ & \\
\hline 2 & Teaching Contents & $\begin{array}{l}\text { Do you think that English teaching materials } \\
\text { suitable with the students' need? Would you give } \\
\text { explanation? }\end{array}$ & \\
\hline 3 & Language used & $\begin{array}{l}\text { What is you opinion about the use of language in } \\
\text { the teaching and learning process is appropriate } \\
\text { with the students' English vocabulary level, } \\
\text { grammar mastery, and the students' language } \\
\text { competencies? }\end{array}$ & \\
\hline 4 & $\begin{array}{l}\text { The Organizations of English Teaching } \\
\text { Contents }\end{array}$ & $\begin{array}{l}\text { Does the organizations of English teaching contents } \\
\text { achieve the teaching and learning objectives } \\
\text { properly? Would you give explanations? }\end{array}$ & \\
\hline 5 & The Teaching-learning process & $\begin{array}{l}\text { Does teaching learning process go in line with } \\
\text { lesson plan and intended teacher's teaching } \\
\text { objectives? }\end{array}$ & \\
\hline 6 & Time Allocation & $\begin{array}{l}\text { Does the time allocation given by the school } \\
\text { sufficient to achive the teaching and learning } \\
\text { objectives?. }\end{array}$ & \\
\hline
\end{tabular}

This is the answer of the question that has been given to the teacher:

a) Yes, they are: English teaching objectives at TMI aim to; 1) Develop students' communication competence in oral and written forms to reach the level of informational literacy. 2) Have an awareness of the nature and importance of English to improve the nation's competitiveness in a global society. 3) Develop students' understanding of the relationship between language and culture.

Therefore, dealing with the communication competence, the nation's competitiveness in a global society, and the relationship between language and culture, the English teaching objectives are considered appropriate with Tunas Mekar English subject curriculum.

b) Yes, I do: The scope of English subject matter at TMI includes; 1) Discourse skills, namely the ability to understand and or produce oral and or written texts realized in four language skills, namely listening, speaking, reading, and writing in an integrated way to achieve informational literacy. 2) Ability to understand and create various short functional texts and monologues and essays in the form of procedure, descriptive, recount, narrative, report, news item, analytical exposition, hortatory, spoof, explanation, discussion, review, and public speaking. The gradation of teaching materials can be seen in the use of vocabulary and rhetorical steps. 3) Supporting competencies, namely linguistic competence (using grammar and vocabulary, sound grammar, and writing), socio-cultural competence (using expressions and actions of language acceptably in various communication contexts), strategic competence (overcoming problems that arise in the communication process in various ways so that communication continues), and discourse-forming competencies (using discourse-forming tools).

c) In my opinion: The use of language in the teaching and learning process is appropriate with the students' English vocabulary level, grammar mastery, and the students' language competencies.

d) Yes, it does: Learning materials are arranged based on ability levels from the easiest to the most complex so that students can learn and develop gradually to achieve the teaching and learning objectives properly.

e) Yes, it does.

f) Yes, it does.

The result of teacher's interview above showed that the teacher believed that the English teaching objective had been appropriate with the school's curriculum. The teacher used English during the teaching learning process which trigger the students to speak English.

\section{F. Parents' Questionnaire}

In the questionnaire, the parents answered how their respond in English. The folowing questions are the parents' questionnaire that indicates the parents' respond about their children need in the teaching and learning process. Here are the statements which are given to parents.

- I consider the English material taught by the teacher is in accordance with the children' need.

- I see that the English material given by the teacher is appropriate with the children' level. 
- I see a significant improvement in my child's English skills.

- I see that children are more fluent in speaking English.

- I see that children are more proficient in writing (grammar) skills in English.

- I see that children have mastered listening skills more in English lessons.

- I see that children quickly understand the contents of short stories in English.

- I see that children are more motivated in learning English based on the method used by the teacher.

- I use English with children in conversations at home.

- I give extra hours to study English at home.

- I give additional hours of learning English at the existing course institution.
- I like to give English educational shows at home.

- I think that the English language of instruction in the classroom is very important.

- I think that native speakers are more appropriate to teach English lessons.

- I consider the facilities and infrastructure provided are adequate for learning English.

- I think that the hours of English lessons need to be increased

- The children's purpose learning English is so that children are able to speak in English.

- I see that children have difficulty in doing the writing exercises in English

- I see children have difficulty in speaking / practicing English.

- I think English is difficult for elementary/primary level children to learn.

TABLE IV. PARENT QUESTIONNAIRE SHEET

\begin{tabular}{|c|c|c|c|c|}
\hline Statement & Very Disagree & Disagree & Agree & Very Agree \\
\hline 1 & $20 \%$ & $40 \%$ & $20 \%$ & $20 \%$ \\
\hline 2 & $15 \%$ & $30 \%$ & $40 \%$ & $15 \%$ \\
\hline 3 & $20 \%$ & $25 \%$ & $35 \%$ & $20 \%$ \\
\hline 4 & - & $5 \%$ & $15 \%$ & $70 \%$ \\
\hline 5 & - & $65 \%$ & $20 \%$ & $15 \%$ \\
\hline 6 & - & $25 \%$ & $25 \%$ & $50 \%$ \\
\hline 7 & - & $15 \%$ & $40 \%$ & $45 \%$ \\
\hline 8 & - & $30 \%$ & $50 \%$ & $20 \%$ \\
\hline 9 & - & $10 \%$ & $20 \%$ & $70 \%$ \\
\hline 10 & - & - & $50 \%$ & $50 \%$ \\
\hline 11 & - & - & $20 \%$ & $80 \%$ \\
\hline 12 & - & - & $10 \%$ & $90 \%$ \\
\hline 13 & - & - & $20 \%$ & $80 \%$ \\
\hline 14 & - & - & $15 \%$ & $85 \%$ \\
\hline 15 & - & - & $80 \%$ & $20 \%$ \\
\hline 16 & $5 \%$ & $5 \%$ & $70 \%$ & $30 \%$ \\
\hline 17 & - & - & $20 \%$ & $80 \%$ \\
\hline 18 & - & - & $40 \%$ & $60 \%$ \\
\hline 19 & $55 \%$ & $45 \%$ & - & - \\
\hline 20 & $45 \%$ & $50 \%$ & $5 \%$ & - \\
\hline
\end{tabular}

The table 1.3 above showed parents' respond. The data showed that most of parents, $60 \%$, believed that the English material given by the teacher was not appropriate with their children's need. The materials given by the teacher did not cover all English skills. Even there was a significant improvement on their child's speaking, the children still found difficulties in writing.

\section{G. Discussion}

1) The teaching and learning process

At some point of studying hobby within the magnificence, the instructor opened the lesson by greeting the students. The teacher once in a while reviewed a few previous materials and then persisted the coaching and mastering pastime through turning in the following materials. The trainer also organized her/himself earlier than coaching through the use of systematic lesson plan. It changed into in step with the teacher's statements in order to make the systematic teaching manner. in the coaching and studying technique, she used diverse methods to create conducive studying environment. It also depended on what sorts of substances given to the scholars. It matched with the idea of Tunas Mekar Indonesia Philosophy in which it is crucial to use many styles of methods and media to create the relaxed gaining knowledge of hobby to the students. The instructor used varies method in teaching so one can create the joyful mastering situation to the scholars. 
The Students involvement in the teaching and learning process

In the course of the commentary, the author noticed that the instructor tried to contain the students actively within the learning manner. The trainer frequently used questions that typically related to the topic being taught, namely building know-how of area. To encourage the pupil's participation, the instructor gave some students or all college students in the elegance some questions related to the material being taught and consequently the scholars ought to solution it at once. teaching English is considered as incorporated abilities specifically listening, reading, speaking and writing. The teacher conducted the teaching and getting to know manner either in a school room or out of doors the classroom, inclusive of, statement the sector, and interviewing human beings.

2) Teacher's role

Coping with the instructor's roles in magnificence, he acted as a motivator, a facilitator, and a guide. In this situation, the instructor advocated the student's motivation to be more active and innovative in teaching mastering process. teaching technique utilized by the trainer become decided on correctly based totally on the teaching fabric being taught to the scholars that directly affected to the adjustments of the instructor's roles. The trainer also used many teaching strategies a good way to make the students involved actively in teaching gaining knowledge of method.

\section{3) Students' Role}

College students are the vital doer or issue of teaching and mastering technique. They had been advocated for being lively and creative during commands. furthermore, while the instructor provided some collection of coaching gaining knowledge of sports, they have been demanded to be energetic and creative in constructing their knowledge with the new data's.

\section{CONCLUSION AND SUGgestion}

The material development is needed in the classroom teaching to achieve the instructional goal since the curriculum made is still broader, the syllabus design is the way to bring the material sharper to the students. So that the materials design must suitable and adjust to the syllabus and students needs considering the classroom contains of diverse learners.

Therefore the teachers' capability is important to decide what materials in the course book chosen for the learners in other words the teachers creativity is also influence in the learning process. According to the findings that the objectives of school syllabus are not acheived which means some syllabus has been achieved and some are not. This condition occurs because the teacher is too focus to make students being active in speaking, but in some aspects, the students still find difficulties.
The syllabus objectives are not appropriate because some of the students in the classrom still can be able to read smoothly. On the other hand, the students are required to absorb the materials that force them to read smoothly. The language in the classroom has been appropriate because the teacher speak english in the classroom. Maybe the problem happens for the writing that the students still are influeced by Indonesian spelling. For example, the word 'I can read", some students still write "Ai ken rid" which indicate there is influence from Bahasa Indonesia. The teacher needs to adjust the materials based on the events in the school every term because the teacher need to consider the time allocation about teaching materials and involving school event. The practical of lesson plan sometimes does not go in line with the lesson plan because the time allocation because in the school always has events every term which affect the teaching and learning process.

\section{A. Students and teaching learning process}

Students feel difficulty in understanding English material grammar, reading, and writing but almost all students fluently in speaking ability.

\section{B. The level of material is too difficult.}

Students can speak fluently but they can not write down the sentence.For example:I can do that Sir. Students write down: I ken du ded Ser

\section{Teachers}

- Feel that the time allocation should be more added.

- Teaching resources shoul be more added.

To sum up, the school must provide curriculum or syllable which is appropriate with the students' need. The material given must be able to improve four aspects of English; listening, speaking, reading, and writing. If the school has to do so, the goal of learning will be achieved well.

\section{ACKNOWLEDGMENT}

The co-author would like to express his very great appreciation to the ULICOSS committee and the reviewer who gave their suggestion and input for the benefit of this article.

\section{REFERENCES}

[1] Richard, J.C. (2001). Curriculum development in language teaching. Cambridge: Cambridge University Press.

[2] Nababan, P. W. (1991). Language in education: The case of Indonesia. International Review of Education, 37(1), 115-131.

[3] Zein, M. S. (2017c). Language-in-education policy on primary EFL: The case of Indonesia. International Journal of Pedagogies \& Learning, 12(2), 133-146

[4] Richard, J. C. \& Schmidt, R. 2002. Longman Dictionary of Language Teaching and Applied Linguistics 3rd Edition. Edinburgh: Pearson Education Limited.

[5] Brindley, G. (1989). The role of needs analysis in adult ESL programme design. In R.K. Johnson (Ed.), The second 
language curriculum (pp. 63-77). Cambridge: Cambridge University Press

[6] Tiwari, S.R. 2008. Teaching of English. New Delhi: S. B. Nangia APH Publishing Corporation.

[7] Choudhury, N.R. 1998. Teaching English in Indian Schools. New Delhi: S. B. Nangia APH Publishing Corporation.

[8] Cowling, J. D. (2007). Needs Analysis: Planning a syllabus for a series of intensive workplace courses at a leading Japanese company. Japan: Elseiver

[9] Gilabert, R. (2005). Evaluating the use of multiple sources and methods in needs analysis: A case study of journalists in the autonomous community of Catalonia (Spain). In M.H. Long (Ed.), Second language needs analysis (pp. 182-199). Cambridge: Cambridge University Press

[10] Nation, I. \&. (2010). Language Curriculum Design. New York: Routledge.

[11] Richterich, R., \& Chancerel, J.-L. (1977). Identifying the needs of adults learning a foreign language. Oxford: Pergamon Press.

[12] West, R. (1994). Needs analysis in language teaching. Language Teaching, 27, 1-19.
[13] Jeczelewski, S. (2016). Needs analysis, course design and evaluation of business English. (B.A. Research Project), University of Iceland School of Humanities Department of English.

[14] Long, M.H. (2005a). Methodological issues in learner needs analysis. In M.H. Long (Ed.), Second language needs analysis (pp. 19-76). Cambridge: Cambridge University Press.

[15] S. E. A. Groothuijsen, L. H. Bronkhorst, G. T. Prins \& W. Kuiper (2020) Teacher-researchers' quality concerns for practice-oriented educational research, Research Papers in Education, 35:6, 766-787

[16] lalou, A. (2001). Reevaluating curricular objectives using students' perceived needs: the case of three language programs. Foreign Language Annals, 34(5), 453-469.

[17] Long, M.H. (2005b). Overview: A rationale for needs analysis and needs analysis research. In M.H. Long (Ed.), Second language needs analysis (pp. 1-16). Cambridge: Cambridge University Press 